No. 9-Subcommittee on Applications to Pumps, Fans and Blowers. P. H. Adams, Chairman.

No. 10-Subcommittee on Applications of Electrical Energy in Industrial Heating. M. J. McHenry, Chairman.

No. 11-Subcommittee on Rubber Industry. W. E. Date, Chairman.

A complete roster of the several subcommittees will be found in the Year Book. These subcommittees have worked. Give them and their chairmen the full credit for our work of this term.

The Committee has conducted one Institute meeting at Akron and Cleveland on January 14th, 1921, and under the auspices of Subcommittee No. 11, W. E. Date, Chairman. It was a good practical meeting, with plenty of interest.

We have had one thorough committee meeting, viz: on January 14, 1921, at Akron, Ohio, with an attendance of 21 .

I recommend that our committee plan and activities be continued another term. I feel that while our apparent results are not large, that nevertheless a constantly widening group in the Institute is becoming familiar with what we are doing and is taking interest in it. With patience and encouragement the plan will continue to grow in interest and value.

As a portion of this report is submitted a report of progress in the Industry prepared by Mr. W. C. Yates of our Committee and also a full report from the Chairman of each Subcommittee. I recommend these several reports for your careful consideration.

As a committee we have tried hard to make our work of value. It is of value. The work that individuals and groups of two or three have put in with resulting monographs are notable contributions to the Institute files and as Chairman of this Committee, I can do no less than direct attention to them.

I also commend to you the help and efficiency constantly accorded us in our work by the Secretary of the Institute, and those associated with him.

A. G. PIERCE, Chairman.

\section{Industrial and Domestic Power Applications-Progress of the Art During the Year 1920}

By W. C. YATES

Despite the fact that industrial activity slumped decisively during the latter part of the year 1920 , the first three quarters of the year compensated for this to such a degree that the sum total of the industrial and domestic electrical equipment installed during the year was unquestionably greater than in previous years.

The use of electrically-driven domestic machinery, such as washing machines, vacuum cleaners, etc., showed an unprecedented growth until the business depression set in. An astonishing amount of such machinery was installed for the benefit of thousands of housewives, and this was especially true of washing machines. All this required no special developments in the way of motors, switching devices, etc., because suitable types of such electrical equipment were already available.

Turning to the industrial field in general, it may be said that considerable advance was registered in the incorporation of safety features in both motor and and control appliances, especially to the latter. The use of 50-deg. motors as compared to the old 40-deg. ratings increased and there was evidence of much more accurate study of the power required to drive machinery and a closer selection of the motors to do the work. This necessitated in turn the evolution of more overload protective devices, in which connection considerable improvement was made during the year.

In certain fields of industry no particular advance in the art occurred during the year 1920 to be particularly worthy of mentioning. In other fields definite steps in advance were made of which the following are worthy of note:

Mining. The activity in mining was not quite up to that of former years, but a number of interesting large equipments and an unusually large number of small hoist motors from 100 to $250 \mathrm{~h}$. p. were installed or under construction at the close of the year. The McKinney Steel Company's hoist at Bessemer, Michigan, was put into commission. This is the largest d-c. iron ore hoist in the United States. It is driven by a 1650 -h. p. 80 -rev. per min. direct-connected motor.

Steel Mill. A record was made in the number of electric main roll drives put into commission. Improvement was shown in the accuracy of the speed control provided.

Considerable improvement was made in the control devices, especially of the magnetic type for steel mill auxiliary machinery, this improvement having to do with the better wearing qualities of the contactors and consequent longer life of the control equipment.

Machine Tools. In this field the development of motors and controllers for high-speed woodworking machinery stands out most prominently. This application required specially designed motors operated at frequencies as high as 300 cycles.

Textile Industry. An interesting development involved the application of individual drive to a series of tentering machines for starching and drying cloth where three independent rolls, each driven by an individual motor, were tied together by an automatic control equipment that insured the same speed of the fabric through the three machines. This same tie in of two or three machines to run at the same speed was accomplished in the printing of cloth and did away with expensive line shaft equipment very apt to get out of order.

Paper Mill. A new form of sectionalized motor drive for paper machines was developed, each section being driven by an independent motor, the speed of which 
with relation to the speed of the other sections may be regulated to suit the requirements, and when once adjusted will retain this relationship as positively as though geared together.

A typical installation of this new drive was to a paper machine consisting of nine sections and employed in the manufacture of newsprint. This machine is designed for high-speed operation, producing paper 164 inches wide at the rate of $1000 \mathrm{ft}$. per minute. Eight sections of the paper machine are each equipped with a 100-h. p. 136-rev. per min. shunt-wound motor direct coupled, while the reel is driven by a directcoupled motor of $30 \mathrm{~h}$. p. These nine motors are supplied with power on a Ward Leonard system from a $600 \mathrm{kw}$. 250-volt turbine generator, and the speed of the machine as a whole is controlled by the voltage of this generator, the fields of the motor being excited from the same excitation source as the generator. The motors have the same speed regulation from no-load to full load.

The novel feature of the installation consists of 20 -h. p. synchronous motors, one of which is mounted on the base of each of the d-c. motors, and is connected to the main motor by means of a gear and a pair of cones belted together with an eight-inch double-ply belt. The function of these synchronous motors is to rigidly tie together the various sections of the paper machine and maintain a positive unvarying speed relation between them.

Oil Well. The demand for oil well motors continued to increase in both old and new oil fields. The power companies were unable to supply ample power for this purpose.

In Los Angeles County the deepest electrically drilled oil well in the world was completed in June and its depth was $4650 \mathrm{ft}$., this being the "Anita A" well of the Shell Company of California.

Another development of the year in Southern California oil fields was the application of motor drive to deep drilling by the rotary method. This has progressed to a stage which gives every indication of its complete success.

Handling of Coal, Ore, etc. Improvements may be noted in the machines developed to handle coal, ore, and other bulk materials, although this involved no new developments in the electrical apparatus. A particularly interesting installation is the coal loading pier of the Baltimore \& Ohio Railroad Company at Curtis Bay, Md. This was improved last year by the addition of four trimming machines. It is now possible to load a 10,000-ton boat in eight hours.

Elevators. Mention may be made here of the application of the two-speed a-c. motor to elevator service, the motor having two windings and the lower speed being employed for making landings.

Pumps and Fans. Particularly worthy of note is the increased use of synchronous motors in the operation of pumps and fans.
Logging. A unique installation which will undoubtedly have considerable influence on the future of the lumbering industry consists of a combined outfit of electrically-operated yarder and loader hoists which was placed in service in August, 1920, by the Snoqualmie Falls Lumber Company of Snoqualmie, Washington. The yarder is operated by a 200-h. p. 600-rev. per min., three-phase, 60-cycle, 550-volt motor of special construction designed particularly for the very high torque which is essential in yarder service.

The loader, which lifts the logs brought in by the yarder, is a duplex outfit with two hoists, each geardriven by a 75-h. p. slip-ring motor. These hoists are not provided with mechanical brakes, but each has two electrical brakes, one being the standard type and the other a solenoid load brake which has inherent graduated braking characteristics. The reason for this double brake equipment is to secure low and fully controlled lowering speeds when placing the heavy logs on the cars.

Electric Shovels. Considerable improvement was made in the application of electric drive to shovels. The chief improvement involved the use of the Ward Leonard system in the individual drive of the several motions of the equipment.

Advance was made in the design and application of equipment for arc welding, electric furnace work and in other fields. A report of this kind cannot possibly cover the ground in any detail as it is only intended to point out the steady advancement of the art in the broad field of industrial and domestic power.

[This report to the Board of Directors was supplemented by a statement from each of the sub-committee chairmen, giving an outline of the plans and the work accomplished to date of each of the sub-committees.]

\section{TELEGRAPHY AND TELEPHONY COMMITTEE}

\section{To the Board of Directors:}

The following report contains a review of the engineering of Telegraphy, Telephony and Radio Communication during the Institute year 1920-1921.

\section{Wire Communication along RaILROAdS}

Technical developments of the past year have placed the telegraph and telephone departments of railroads in the United States and Canada in a more serviceable condition than they have heretofore been. The work of the technical committees of the Telegraph and Telephone Section of the American Railway Association has been added to by the institution of committees handling the subjects of telephone transmission, radio and wired radio communication, and technical education for employees. A considerable number of new undertakings are now about ready for service trial in the field. Improvements are embodied in recommendations submitted by committees working 